\title{
Neptunium(V) transport in granitic rock : A laboratory scale study on the influence of bentonite colloids
}

\section{Elo, O.}

2019-04

Elo , O , Hölttä , P , Kekäläinen , P , Voutilainen , M \& Huittinen , N M 2019 , ' Neptunium(V) transport in granitic rock : A laboratory scale study on the influence of bentonite colloids ', Applied Geochemistry , vol. 103 , pp. 31-39 . https://doi.org/10.1016/j.apgeochem.2019.01.015

http://hdl.handle.net/10138/301163

https://doi.org/10.1016/j.apgeochem.2019.01.015

publishedVersion

Downloaded from Helda, University of Helsinki institutional repository.

This is an electronic reprint of the original article.

This reprint may differ from the original in pagination and typographic detail.

Please cite the original version. 


\title{
Neptunium(V) transport in granitic rock: A laboratory scale study on the influence of bentonite colloids
}

\author{
O. Elo ${ }^{a, *}$, P. Hölttä ${ }^{a}$, P. Kekäläinen ${ }^{a}$, M. Voutilainen ${ }^{a}$, N. Huittinen ${ }^{b}$ \\ ${ }^{a}$ Department of Chemistry, Radiochemistry, University of Helsinki, P.O. Box 55, FIN-00014, University of Helsinki, Finland \\ ${ }^{\mathrm{b}}$ Helmholz-Zentrum Dresden-Rossendorf, Institute of Resource Ecology, Bautzner Landstr. 400, 01328, Dresden, Germany
}

\section{A R T I C L E I N F O}

Editorial handling by Dr T Schäfer

Keywords:

Neptunium(V)

Bentonite colloids

Granitic rock

Sorption

Column experiments

\begin{abstract}
A B S T R A C T
In the present study neptunium(V) uptake by crystalline granitic rock (Kuru Grey granite) and the role of stable and mobile bentonite colloids (MX-80) on the migration of neptunium(V) was investigated. Two different experimental setups were utilized, batch-type experiments under stagnant conditions and column experiments under flowing water conditions. The uptake of $10^{-6} \mathrm{M}$ neptunium(V) by $40 \mathrm{~g} / \mathrm{L}$ crushed granite in $10 \mathrm{mM}$ $\mathrm{NaClO}_{4}$ was found to be $\mathrm{pH}$-dependent, whereas neptunium(V) uptake by MX-80 bentonite colloids $(0.08-0.8 \mathrm{~g} /$ L) was pH-independent up to a pH-value of approximately 11. Column experiments were conducted in the presence and absence of colloids at two $\mathrm{pH}$ values $(\mathrm{pH}=8$ and 10) and two flow rates $(0.3 \mathrm{and} 0.8 \mathrm{~mL} / \mathrm{h}) \mathrm{in}$ $10 \mathrm{mM} \mathrm{NaClO}_{4}$. The injected neptunium(V) concentration was $2 \times 10^{-4} \mathrm{M}$ and the colloid concentration ranged from 0.08 to $0.32 \mathrm{~g} / \mathrm{L}$. The properties of the flow field in the columns were investigated with a conservative chloride tracer, at the same two flow rates of 0.8 and $0.3 \mathrm{~mL} / \mathrm{h}$. The resulting breakthrough curves were modeled using the analytical solution of advection-matrix diffusion equation. A tailing of neptunium(V) breakthrough curves in comparison to the conservative tracer was observed, which could be explained by a slightly higher retardation of neptunium $(\mathrm{V})$ in the column caused by sorption on the granite. The sorption was in general lower at $\mathrm{pH} 8$ than at $\mathrm{pH} 10$. In addition, the tailing was almost identical in the absence and presence of MX-80 bentonite colloids, implying that the influence of colloids on the neptunium(V) mobility is almost negligible.
\end{abstract}

\section{Introduction}

Several studies have shown that colloid-facilitated transport of radionuclides could have a significant impact on radionuclide migration from hazardous waste sites (Buddemeier and Hunt, 1988; Hursthouse et al., 1991; Kersting et al., 1999; Novikov et al., 2006) and from natural uranium deposits (Short et al., 1988; Vilks et al., 1993). The influence of smectite colloids on the migration of radionuclides in a granitic fracture zone in has been investigated within the Colloid and Radionuclide Retardation experiment (CRR) and the Colloid Formation and Migration (CFM) project (Geckeis et al., 2004; Schäfer et al., 2012; Huber et al., 2011). Laboratory-scale experiments have further shown that the transport of various cationic and anionic metals in porous and fractured media are influenced by the presence of colloids (Ryan and Elimelech, 1996; Artinger et al., 1998; Puls and Powell, 1992; Torok et al., 1990; Buckau et al., 2000; Vilks and Baik, 2001; Alonso et al., 2006) depending on the colloid particle size, ground water composition, flow rate, ionic strength, and quantity.

Colloids in natural waters are generated by erosion, geochemical alteration of minerals and through precipitation (Degueldre et al., 1996). In addition, colloids could form from various natural and engineered barriers in future nuclear waste repositories through erosion of the bentonite clay buffer, copper or steel containers, grouting materials, and the uranium fuel itself (Laaksoharju and Wold, 2005; Finn et al., 1993; Missana et al., 2003; Baik et al., 2007). In this context, several studies have been conducted, both in the absence and presence of colloids, to understand the migration of various radioactive contaminants under future repository conditions and to gain an insight into the potential role of colloids as mobile solid phases for enhanced radionuclide transport in the geosphere.

In the following discussion we will focus on the role of bentonite colloids on radionuclide migration. Bentonite is an important part of engineered barrier systems (EBS) and will be used either as single phase or mixed phase (typically mixed with rock or sand) buffer and backfill material in different repository concepts for spent nuclear fuel (SNF) (Hummel, 2008). Bentonite has been chosen as an EBS component due to favorable properties such as a low hydraulic conductivity, its swelling ability, and high specific surface area allowing for efficient uptake

\footnotetext{
* Corresponding author.

E-mail address: outi.elo@helsinki.fi (O. Elo).
} 
of potential released radionuclides from the SNF (Missana et al., 2003; 2011). Drawbacks of the buffer material are related to its sensitivity towards the overall salt content of the ground water, where colloid generation has been shown to occur for ionic strengths below the critical coagulation concentration (CCC) (García-García et al., 2007; Tombácz and Szekeres, 2004; Lagaly and Ziesmer, 2003). Such ionic strengths and the subsequent formation of stable and mobile bentonite colloids from the EBS could be reached when the meltwater dilutes the ground water after a possible glacial period. A combination of mobile bentonite colloids and their strong sorption capacity may lead to an unwanted, enhanced mobility of released radionuclides in the geosphere. In general, strong retention on the clay material has been demonstrated for radionuclides in the tri- and tetravalent oxidation states (Zhao et al., 2008; Huber et al., 2011; Verma et al., 2014; Begg et al., 2015), while sorption of hexavalent radionuclides, such as uranium (VI), occurs readily but seems to depend on both the bentonite material as well as the solution conditions (Missana et al., 2004; Bachmaf et al., 2008; Ren et al., 2010; Huber et al., 2011; Zong et al., 2015). Uptake studies conducted with pentavalent actinides such as neptunium(V) or plutonium(V) are rather scarce, however, sorption isotherm data show that moderate uptake of neptunium(V)/plutonium(V) occurs in the alkaline pH range (Sabodina et al., 2006; Begg et al., 2015; Li et al., 2015) and that sorption can be enhanced in the presence of Fe-impurities in the bentonite solid (Verma et al., 2017). In addition to the batch-type experiments, an enhanced radionuclide mobility due to the presence of bentonite colloids under flowing ground water conditions has been observed to take place for tri- and tetravalent radionuclides and their inactive analogues (Möri et al., 2003; Schäfer et al., 2004; Geckeis et al., 2004; Missana et al., 2008; Dittrich et al., 2015). The situation is very different for both neptunium(V) and uranium (VI), where close to no impact of bentonite colloids on the breakthrough properties of these radioelements has been found (Möri et al., 2003; Schäfer et al., 2004; Geckeis et al., 2004). For both radionuclides an inconclusive breakthrough behavior, requiring more interpretation, was found in Möri et al. (2003), while the breakthrough of both elements investigated in Geckeis et al. (2004) was faster than observed for the conservative tracer $\left(\mathrm{I}^{-}\right)$. It was assumed that the rapid flow through open channels did not allow for sufficient interaction between the tracers and rock surface. Further attempts to explain neptunium(V) migration through fractured rock in the presence of colloids have, to our knowledge, not been made, implying that definite conclusions about the fate of neptunium in the presence of colloids cannot be drawn. As Np-237, due to its long half-life $\left(2.144 \times 10^{6} \mathrm{a}\right)$, is considered as a significant dose contributor in the SNF repository after 100000 years (Hursthouse et al., 1991; Kaszuba and Runde, 1999; Zhao et al., 2014), understanding the migration behavior of neptunium(V) and the potential influence of colloid transport in the geosphere is mandatory.

Thus, the present study aims at describing neptunium(V) uptake by crystalline granitic rock and bentonite colloids under stagnant conditions in batch-type experiments and the role of stable and mobile bentonite colloids on the migration of neptunium(V) through intact granite rock columns under flowing water conditions. The materials used in this study are bentonite colloids prepared from MX-80 bentonite and Kuru Grey granitic rock. Neptunium(V) sorption on these solid phases under stagnant conditions was studied as a function of $\mathrm{pH}$, solid concentration, and neptunium(V) concentration. The column experiments were conducted under ambient air both in the absence and presence of bentonite colloids. The drill core column experiments were modeled using an analytical solution of advection-matrix diffusion equation. The modeling aims at describing the flow field in the experiments in order to better understand the behavior and interaction of neptunium(V) with the rock matrix and the bentonite colloids.

\section{Materials and methods}

\section{1. $M X-80$ colloids}

The MX-80 bentonite used in this study is sodium-rich Wyoming Volclay-type bentonite provided by $\mathrm{B}+\mathrm{Tech}$. The bentonite has been thoroughly characterized by Kumpulainen and Kiviranta (2010) and it was used as a source of bentonite colloids in the present study. The clay consists of $79.1 \%$ smectite, $7.5 \%$ muscovite, $4.4 \%$ quartz, $3.1 \%$ calcite, $1.7 \%$ plagioclase, and minor amounts of other accessory minerals (Kumpulainen and Kiviranta, 2010). The cation exchange capacity (CEC) is $0.89 \mathrm{eq} / \mathrm{kg}$ (Kumpulainen and Kiviranta, 2010) and the BET surface area was measured to be $28.9 \mathrm{~m}^{2} / \mathrm{g}$ (this study). The chemical composition and CEC were analyzed from the solid Volclay bentonite powder, hence, slight differences in both the chemical composition and the CEC of the colloid suspension used in this study may exist. The elemental composition of the MX-80 bentonite colloidal fraction $(25-450 \mathrm{~nm})$ has been analyzed earlier by Lahtinen et al. (2010) using ICP-MS. The calcium concentration was below limit of quantitation suggesting a homoionic form $\left(\mathrm{Na}^{+}\right)$of the colloid suspension.

The MX-80 colloid solutions were prepared by mixing $5 \mathrm{~g}$ of solid MX-80 bentonite powder and $500 \mathrm{~mL}$ of $10 \mathrm{mM} \mathrm{NaClO}_{4}$. In batch sorption experiments where a constant $\mathrm{pH}$ was required, the $10 \mathrm{mM}$ $\mathrm{NaClO}_{4}$ background electrolyte was buffered either to $\mathrm{pH} 8$ with $10 \mathrm{mM}$ TRIS (tris-hydroxymethyl-aminomethane), or to $\mathrm{pH} 9$ or 10 with $10 \mathrm{mM}$ CHES ((cyclohexylamino)ethanesulfonic acid). Buffered solutions were prepared before addition of MX-80 bentonite to avoid changes in colloid stability caused by changes in ionic strength and $\mathrm{pH}$. Therefore, each colloid suspension was prepared individually leading to dissimilar colloid concentrations in the different batch sorption experiments. In the column experiments, a buffer was not used. The electrolyte solution was in a sealed flask and the $\mathrm{pH}$ was checked daily (except during the weekend) and re-adjusted if necessary. The outflow solution in the fraction collector was in contact with ambient air. The $\mathrm{pH}$ of the outflow solution was measured before the experiments from the solution collected in a sealed bottle.

All bentonite suspensions were allowed to equilibrate under constant shaking for 7 days prior to extraction of the colloidal material. After the equilibration time, the colloidal material was separated by centrifuging the MX-80 solutions for $20 \mathrm{~min}$ at $12000 \times g(12000 \mathrm{rpm})$. The centrifugation procedure removed particles with a diameter greater than $500 \mathrm{~nm}$, resulting in a mean colloid particle diameter of approximately 200-300 nm, as confirmed by Photon Correlation Spectroscopy (PCS). Both the colloid particle size and the colloid concentration were determined from the centrifuged supernatants. The determination of the colloid concentration is described in the following paragraph.

To ensure that the colloids remain stable under the chosen experimental conditions, their stability in $10 \mathrm{mM} \mathrm{NaClO}_{4}$ at around $\mathrm{pH} 8$ without a buffer was followed during 53 days. Five parallel samples were sealed in cuvettes for size or Zeta-potential measurements to avoid the effect of $\mathrm{CO}_{2}$. The colloid particle size distribution and zeta potential were analyzed applying PCS and microelectrophoresis, respectively (Malvern Zetasizer Nano ZS). During the first 30 days, the mean particle diameter was $215 \pm 54 \mathrm{~nm}$. Considering the whole follow-up time, the mean particle diameter was $384 \pm 87 \mathrm{~nm}$, the mean colloid concentration was $0.13 \pm 0.04 \mathrm{~g} / \mathrm{L}$ and the mean zeta potential value $-54.9 \pm-6.6 \mathrm{mV}$, indicating the existence of a stable bentonite colloid dispersion. The colloid concentration, fed through the column and the eluted amount of colloids in the colloid breakthrough fractions was estimated from the PCS measurement parameter "derived count rate" based on the equation given in Fig. 1 (Niemiaho, 2013). In the calibration curve, the colloid concentration was back-calculated from the structural formula of MX- 80 based on the aluminum concentration in bentonite colloid dispersions determined with ICP-MS (Agilent $7500 \mathrm{ce})$. The derived count rate is roughly proportional to the concentration of particles and can be used to estimate the relative 


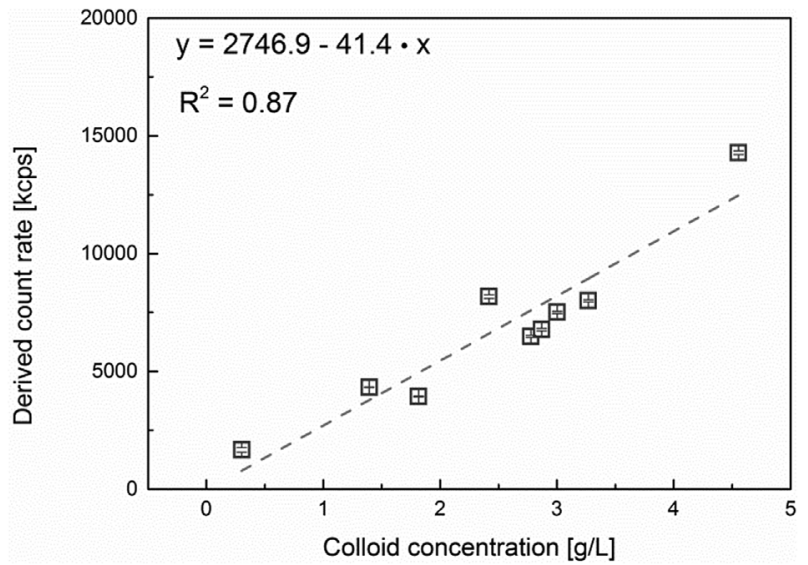

Fig. 1. The correlation between the PCS count rate and the colloid concentration calculated from the aluminum content in bentonite analyzed using ICP-MS (Niemiaho, 2013).

concentration of colloids even though the correlation between the ICPMS and PCS measurements in range $<1 \mathrm{~g} / \mathrm{L}$ is rather uncertain. PCS was also used to follow the overall colloid particle size eluted from the columns.

\subsection{Kuru Grey granite}

Kuru Grey granite was obtained from Kuru Quarry, Tampereen kovakivi Oy, Finland and it has previously been characterized by Hölttä et al. (2004; 2008). The rock matrix of Kuru Grey granite is intact, finegrained, non-foliated, and equigranular with a density of $2660 \mathrm{~kg} / \mathrm{m}^{3}$. It is composed of $36 \%$ potassium feldspar, $35 \%$ quartz, $21 \%$ plagioclase, and $8 \%$ amphibole and micas. The total porosity of the granite is $0.47 \%$ as determined by Jokelainen et al., (2009). For the neptunium(V) batch sorption studies the Kuru Grey granite was crushed and separated into particles that were $0.1-1 \mathrm{~mm}$ in diameter. For the column experiments an intact drill core Kuru Grey granite column was used.

\subsection{Batch sorption experiments}

The $\mathrm{pH}$-dependent sorption of neptunium(V) on bentonite colloids was studied both in ambient air and $\mathrm{N}_{2}$-atmosphere to investigate the influence of carbon dioxide on the neptunium(V) retention and to simulate anoxic conditions in a final repository. Neptunium(V) sorption on crushed Kuru Grey granite at constant neptunium(V) concentration of $10^{-6} \mathrm{M}$ and granite concentration of $40 \mathrm{~g} / \mathrm{L}$ was investigated under ambient air atmosphere only, to simulate the experimental conditions of the column experiments. The neptunium(V) concentration was kept constant at $10^{-6} \mathrm{M}$, the colloid concentration ranged from 0.08 to $0.8 \mathrm{~g} / \mathrm{L}$, depending on the remaining colloid concentration in the supernatant after centrifugation, as explained above (section 2.1). Iso-

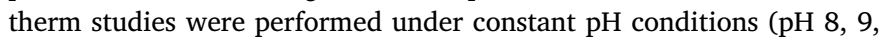
and 10) in $\mathrm{N}_{2}$-atmosphere as a function of neptunium(V) concentration $\left(10^{-10}\right.$ to $\left.5 \times 10^{-6} \mathrm{M}\right)$. TRIS and CHES buffers were used to achieve a constant $\mathrm{pH}$ in the experiments. The final colloid concentrations for isotherm experiments at $\mathrm{pH} 8,9$, and 10 were $0.10,0.06$, and $0.18 \mathrm{~g} / \mathrm{L}$, respectively. $10 \mathrm{mM} \mathrm{NaClO}$ was used as a background electrolyte throughout the experiments. The sample $\mathrm{pH}$ was adjusted with 0.01-1 M NaOH and $\mathrm{HClO}_{4}$ solutions. All samples were allowed to equilibrate under constant shaking for 7 days. Thereafter all solid material including the colloids was separated by ultracentrifugation at $690000 \times g(90000 \mathrm{rpm})$ allowing the determination of the non-sorbed neptunium $(V)$ concentration from the supernatant. The neptunium(V) concentration was determined by liquid scintillation counting (Quantulus) using $\alpha / \beta$ - discrimination to separate out the $\beta$ disintegrations from the Np-237 daughter nuclide Pa-233.

\subsection{Column experiments}

The effect of bentonite colloids on neptunium(V) migration was studied under flowing water conditions in a drill core column, which has been used earlier in parallel with block-scale experiments to evaluate the simplified radionuclide transport concept (Hölttä et al., 2008).

The intact drill core, $28 \mathrm{~cm}$ and $1.4 \mathrm{~cm}$ in diameter, was placed in the Glass Econo-Column ${ }^{\circ} 30 \mathrm{~cm}$ long and $1.5 \mathrm{~cm}$ in diameter, forming a flow channel in the $0.5 \mathrm{~mm}$ gap between the rod and tube. The height of the column was adjusted with a Bio-Rad Flow Adaptor. Before the construction of the column, the drill core was cleaned ultrasonically in ethanol to remove dust and any remnants from the drilling procedure. The column experiments were performed under ambient air conditions. The solution was continuously pumped through the column and the effluent was fed to a fraction collector for determining the breakthrough of the tracer. The feed solution was replaced with the colloid solution when experiments in the presence of colloids were conducted. Known volumes of tracers were injected in the column through an injection loop with a volume of $12 \mu \mathrm{L}$. The total volume of the flow channel in the column is $6.4 \mathrm{~mL}$ which is 500 times higher than the volume of injection loop indicating that the tracer pulse is diluted after injection. Flow rates were controlled with a peristaltic pump and determined by collecting and weighing several parallel fractions of the background electrolyte that eluted through the columns in $1 \mathrm{~h}$. The experimental setup is presented in Fig. 2.

Matrix diffusion and dispersion are the most important transport mechanisms for radionuclides in a rock matrix (Moreno et al., 1997).
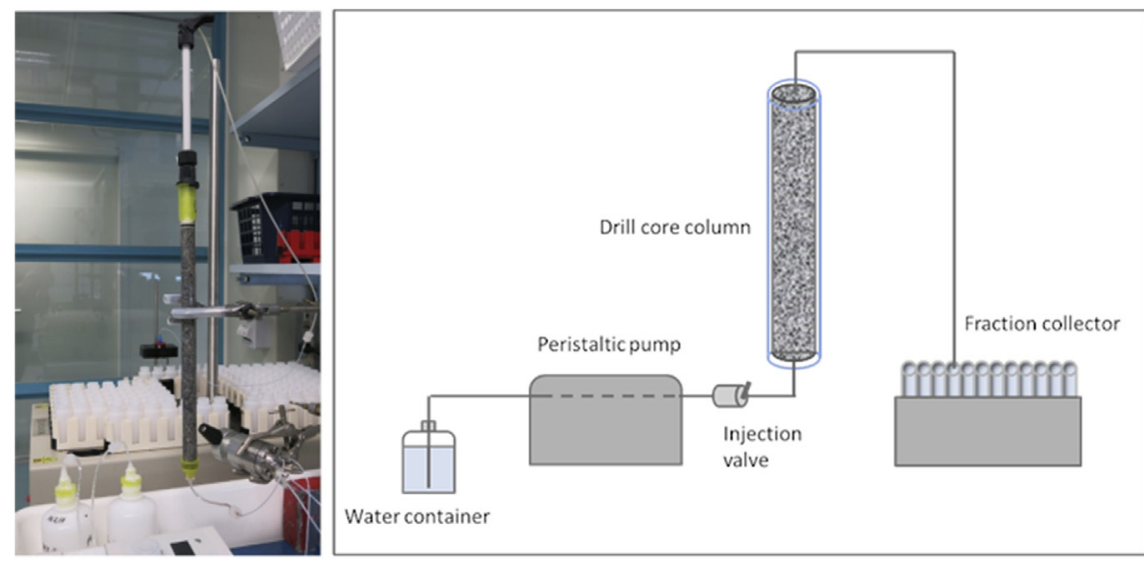

Fig. 2. Experimental set-up and schematic design for the column experiments. The intact $28 \mathrm{~cm}$ long drill core with a diameter of $1.4 \mathrm{~cm}$ was placed inside a column to form an artificial $0.5 \mathrm{~mm}$ aperture flow channel between the core and the column walls. 


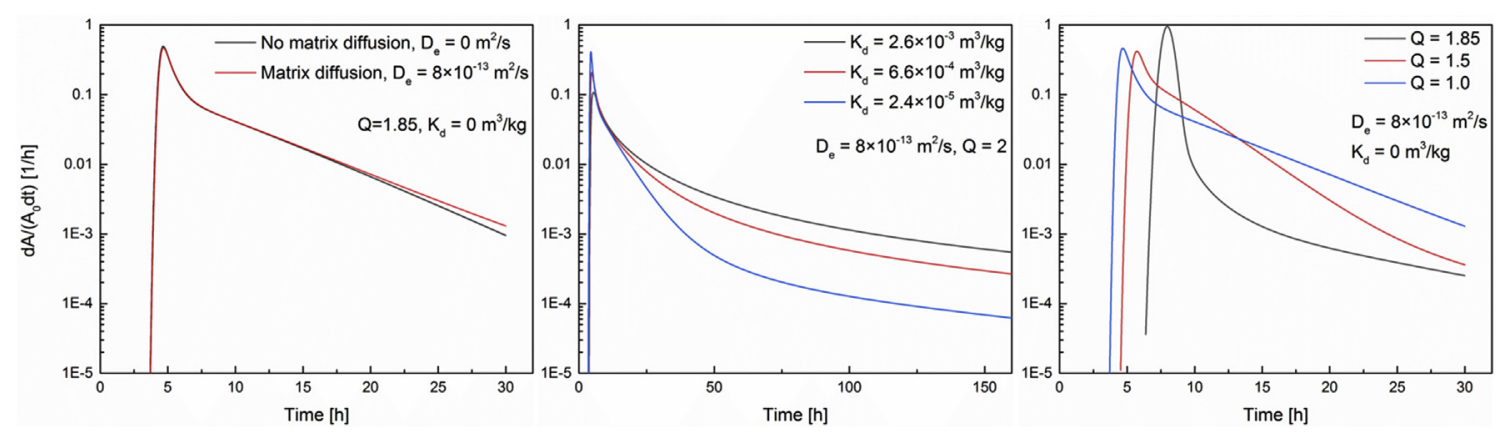

Fig. 3. The influence of the effective diffusion coefficient (left), $K_{d}$ (middle) and scaling of flow velocity (right) on the breakthrough curves.

Matrix diffusion can only be seen at very slow flow rates (Hölttä et al., 1996; 2008). The flow rates of $0.3 \mathrm{~mL} / \mathrm{h}$ and $0.8 \mathrm{~mL} / \mathrm{h}$ for this study were selected based on a previous study with the same drill core column (Hölttä et al., 2008). At the selected flow rates, the transport of the conservative tracer is dominated by hydrodynamic dispersion caused by a heterogeneous velocity field together with transverse molecular diffusion in the fracture. The transverse diffusion in the fracture smooths out variable flow rates for different streamlines in the circular slit around the core. The effects of matrix diffusion were shown in mobile iodine breakthrough curves only at a very low flow rate of $0.04 \mathrm{~mL} / \mathrm{h}$, which excludes the possible disturbing effects of the matrix in this study. The two different flow rates were chosen to elucidate the effect of sorption kinetics on the breakthrough of neptunium(V). The flow field in the column was characterized without colloids using a conservative tracer, chloride ( $\mathrm{Cl}-36)$. The chloride concentration in the injected tracer volume was $8.7 \times 10^{-2} \mathrm{M}$, which quickly dilutes inside the column. The total liquid volume in the first $0.5 \mathrm{~cm}$ of the column dilutes the injected tracer by a factor of almost 10, which is below the ionic strength of $10 \mathrm{mM} \mathrm{NaClO}_{4}$ used as background electrolyte.

The experimental conditions in terms of $\mathrm{pH}$ were selected based on the results obtained in our sorption experiments (see section 3.1). At pH 8 , sorption of neptunium(V) on granite is low, and increasing at $\mathrm{pH} 10$. Thus, $\mathrm{pH}$ values of 8 and 10 were selected for the column experiments and $10 \mathrm{mM} \mathrm{NaClO}_{4}$ was used as a background electrolyte to ensure comparable conditions to our previous study (Elo et al., 2017) where we investigated neptunium(V) sorption on Na-montmorillonite extracted from the MX-80 bentonite. The rock surfaces in the column were equilibrated by continuously feeding $10 \mathrm{mM} \mathrm{NaClO}_{4}$ through the column for several months up to one year. The column was preconditioned at the wanted $\mathrm{pH}$-values by feeding the background electrolyte through the column for at least two weeks prior to experiments. The $\mathrm{pH}$ value from the collected solution was determined before the experiment. Neptunium(V) transport through the granite columns was monitored in the absence and presence of bentonite colloids. In both experiments, a rather high neptunium(V) concentration of $2 \times 10^{-4} \mathrm{M}$ was chosen to assure that neptunium could be measured from the collected fractions. However, due to dilution of neptunium $(\mathrm{V})$ inside the column, a concentration of $5 \times 10^{-6} \mathrm{M}$ (maximum concentration used in our isotherm experiments) is reached already in the first $2 \mathrm{~cm}$ (out of $28 \mathrm{~cm}$ ) in the column. In the experiments conducted in the presence of bentonite colloids, the neptunium(V) tracer was injected into a constant and stable flow of bentonite suspension with a colloid concentration ranging from 0.08 to $0.32 \mathrm{~g} / \mathrm{L}$. The eluted neptunium(V)/colloid fraction was collected with a fraction collector and the neptunium(V) concentration was determined from each fraction with LSC as explained above. Prior to the $\alpha / \beta$-counting, the colloid concentration in the solution eluted through the column was determined by photon correlation spectroscopy (PCS) and the standard series presented in Fig. 1.

\subsection{Analytical modeling}

The breakthrough curves of the column experiments with chloride and neptunium(V) in the absence and presence of MX-80 bentonite colloids were modeled using the analytical solution of advection-matrix diffusion equation in cylindrical coordinates (see Kuva et al., 2016 for details). The analytical solution for the problem was constructed using the methods reported previously (Kekäläinen et al., 2011; Kekäläinen, 2014; Kuva et al., 2016). Recently, the model has been further developed so that it is possible to take into account the channeled flow field (Voutilainen et al., 2018). The model takes into account: (i) 1D diffusion in the flow field in direction of advection, (ii) 1D radial diffusion in the rock matrix, (iii) sorption on mineral surfaces in the rock matrix, and (iv) the channeled flow field between the cylindrical sample and the pipe surrounding the sample. The analytical solution was derived for a Dirac delta function input starting from partial differential equations describing the phenomena given above. The equations were solved by first writing them in dimensionless form, finding the eigenvalues which are a combination of Bessel functions in the cylindrical case, and solving the partial differential equations in Laplace space.

As a first step, the effect of the tubes before and after the granite column was subtracted from the total flow-through time. Thereafter the flow velocity was scaled to get the raising part of the breakthrough curve to the correct position. This was done by keeping the flow rate constant (measured value) and setting part of the water in stagnant state. Here, a scaling factor of 1 means no scaling and values greater than one mean that parts of the channel contains stagnant water (see Fig. 3). Finally, the diffusion coefficient of chloride/neptunium(V) in water was adjusted to enable fitting of the late part of the breakthrough curve. The rock matrix did not affect the breakthrough curves of chloride and, thus, it could be used to characterize the flow field (see Fig. 3). In contrast, the matrix affected the breakthrough curves of neptunium(V) due to moderate sorption on granite. Thus, the $K_{d}$ of neptunium(V) was adjusted to fit the late part of the breakthrough curves. In Fig. 3 the influence of matrix diffusion (left), $\mathrm{K}_{\mathrm{d}}$ (middle), and the stagnant-to- flowing water ratio (right) on the breakthrough curves are demonstrated. The values for porosity and the effective diffusion coefficient of Kuru Grey granite were selected according to previously determined values, i.e. $0.47 \%$ (Jokelainen et al., 2009) and $8 \times 10^{-13} \mathrm{~m}^{2} / \mathrm{s}$ (Ikonen et al., 2016), respectively.

\section{Results and discussion}

\subsection{Batch sorption experiments}

The pH-dependent sorption of neptunium(V) onto MX-80 bentonite colloids and crushed Kuru Grey granite is presented in Fig. 4 as sorption percentages (left) and $\mathrm{K}_{\mathrm{d}}$ values (right). Each data point represents the average of duplicate measurements, and the error bars are standard deviations of these measurements.

For neptunium(V) uptake by MX-80 bentonite colloids in $\mathrm{N}_{2}$ - 

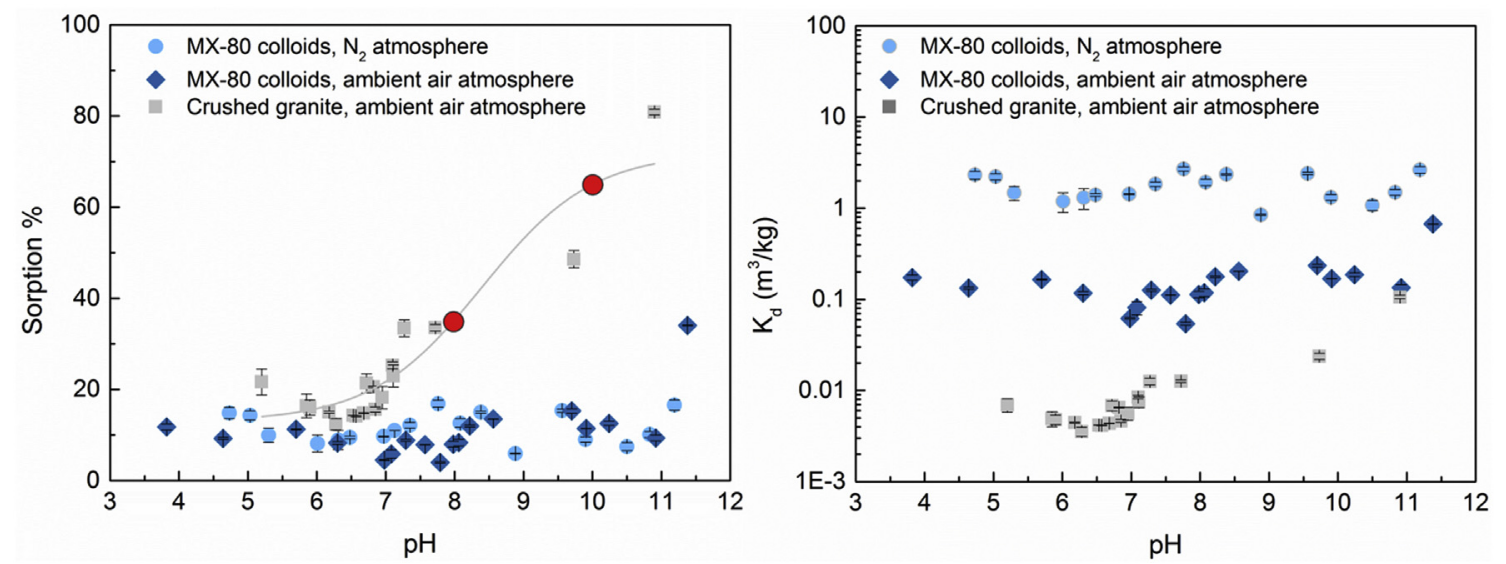

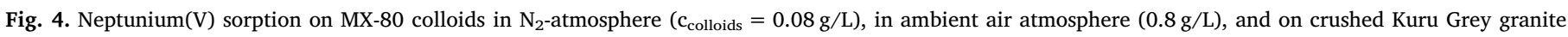
(40 g/L).

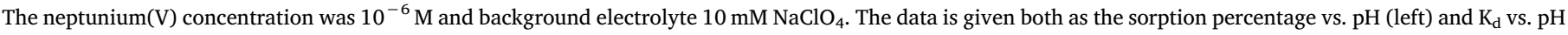
(right). For crushed granite, a Boltzmann Fit of the sorption percentage vs. $\mathrm{pH}$ graph was made to select $\mathrm{pH}$ values (red spheres) for the column experiments.

atmosphere, the sorption percentage remains almost stable up to a $\mathrm{pH}$ value of $11.2\left(16 \%, \mathrm{~K}_{\mathrm{d}}=2.6 \pm 0.2 \mathrm{~m}^{3} / \mathrm{kg}\right)$. In addition, no clear difference in the sorption percentage between $\mathrm{N}_{2}$-atmosphere and ambient air atmosphere can be seen except at $\mathrm{pH} 11.4$ (34\%, $\mathrm{K}_{\mathrm{d}}=0.671 \pm 0.003 \mathrm{~m}^{3} / \mathrm{kg}$ ). This implies that the formation of neptunium(V)-carbonate complexes can be neglected at the chosen experimental conditions $(\mathrm{pH} \leq 10)$ in the column experiments which, further, allows us to draw conclusions about the influence of colloids on the neptunium $(\mathrm{V})$ mobility in these experiments. A difference between $\mathrm{N}_{2}$ and ambient air atmosphere can be seen in the $\mathrm{K}_{\mathrm{d}}$ values. This difference is constant over the whole $\mathrm{pH}$-range and cannot, therefore, be attributed to the presence of carbon dioxide which could result in formation of soluble neptunium(V)-carbonate complexes in the neutral to alkaline $\mathrm{pH}$-range. The difference most likely arises from the absolute colloid concentration which is used in the calculation of the $\mathrm{K}_{\mathrm{d}}$-value. As seen in Fig. 1, low colloid concentrations (below $1 \mathrm{~g} / \mathrm{L}$ ) are represented by only one data point in the calibration curve. Therefore, a larger uncertainty is expected for the very low colloid concentration range (such as the $0.08 \mathrm{~g} / \mathrm{L}$ used in experiments conducted in $\mathrm{N}_{2}$ atmosphere) in comparison to $0.8 \mathrm{~g} / \mathrm{L}$ (used at ambient conditions) and beyond. The constant sorption behavior over the entire examined $\mathrm{pH}$ range is not in agreement with our previous studies, investigating neptunium(V) uptake by montmorillonite extracted and purified from MX-80 bentonite by B + Tech and MX-80 bentonite colloids (Elo, 2014; Elo et al., 2017). In those studies, a pH-dependent uptake of neptunium (V) was found, which could be described by the presence of a small amount of ion exchanged neptunium(V) in the acidic to circumneutral $\mathrm{pH}$ range and two surface complexes at $\mathrm{pH}$-values above 7. Also, the used solid/liquid -ratio was roughly $3.5 \mathrm{~g} / \mathrm{L}$ which was the value at the plateau where maximum neptunium(V) sorption was obtained. Furthermore, a $K_{d}$ value of 2.6 (observed in the present study over the entire investigated $\mathrm{pH}$-range) was obtained for neptunium(V) sorption on montmorillonite only at $\mathrm{pH}$-values exceeding 10 . Both the $\mathrm{pH}$-independent behavior and the high $\mathrm{K}_{\mathrm{d}}$ obtained in the present study for neptunium(V) sorption on MX-80 bentonite colloids imply, that a large amount of neptunium is adsorbed on the colloids through cation exchange on clay surfaces exhibiting permanent negative charge. This is in line with the overall CEC $(0.89 \mathrm{eq} / \mathrm{kg})$, which can hold the overall amount of $\mathrm{NpO}_{2}{ }^{+}$cations present in the clay suspensions, even for the lower colloid concentration of $0.08 \mathrm{~g} / \mathrm{L}$. The overall low sorption percentage can be attributed to the low concentration of colloids used in the present study. However, yet higher colloid concentrations are not expected in natural scenarios and would, thus, not provide a realistic view of their influence on radionuclide mobility in the sub surface environment. In fact, measured colloid concentrations at various underground laboratories such as Äspö, Grimsel, and Gorleben, range from $10^{-6} \mathrm{~g} / \mathrm{L}$ to some milligrams per liter (Degueldre et al., 1988; Jansson, 2009; Laaksoharju and Wold, 2005; Smith and Degueldre, 1993). In the presence of eroded bentonite, however, colloid concentrations of several hundred milligrams per liter $(>0.1 \mathrm{~g} / \mathrm{L})$ have been observed (Jansson, 2009; Missana et al., 2011). Thus, our sorption results for the lower colloid concentration of $0.08 \mathrm{~g} / \mathrm{L}$ can be expected to lie closest to the range expected in the near-field of a future repository for spent nuclear fuel as a result of bentonite erosion.

Neptunium sorption on the crushed granite increases at $\mathrm{pH} 7$ and above. The maximum sorption percentage remains relatively low (81\%, $\mathrm{K}_{\mathrm{d}}=0.106 \pm 0.005 \mathrm{~m}^{3} / \mathrm{kg}$ at $\mathrm{pH} 11$ ). Our results differ somewhat from already published studies on neptunium(V) uptake by granite: Kumata and Vandergraaf (1998), Kienzler et al. (2003), and Park et al. (2012) all found neptunium(V) reduction to neptunium (IV) and a subsequent high retention of the reduced species on granite. Despite the presence of amphibole, a mineral that often contains iron in the structure, in the Kuru Grey granite used in the present study, no reduction of neptunium can be deduced from the low overall uptake in the batch sorption studies and the high recovery of neptunium in the column experiments (discussed later in the text).

Due to the $\mathrm{pH}$-independent sorption of neptunium(V) on MX-80 bentonite colloids throughout the investigated $\mathrm{pH}$ range, experimental conditions for the column experiments (discussed below in section 3.2) were chosen based on the batch sorption data for crushed granite. Here, moderate sorption of neptunium(V) was obtained in the circumneutral $\mathrm{pH}$ range with a slight increase of sorption with increasing $\mathrm{pH}$. Thus, $\mathrm{pH}$ values of 8 and 10 were selected for the column studies based on the Boltzmann Fit of the sorption percentage vs. $\mathrm{pH}$ graph for crushed granite (see Fig. 4 left).

To investigate the neptunium(V) sorption behavior on MX-80 bentonite colloids at varying neptunium concentrations, which is of relevance in the column experiments where a neptunium(V) concentration gradient can be expected in the injection stage, sorption isotherms at constant $\mathrm{pH}$, as a function of neptunium(V) concentration were conducted. Results are presented in Fig. 5. It can be seen that all three ( $\mathrm{pH} 8,9$, and 10) curves are linear with a slope of $0.9 \pm 0.12$, implying that close to ideal sorption conditions (characterized by a slope of 1 ) are maintained over the investigated concentration range.

\subsection{Column experiments}

\subsubsection{Chloride (Cl-36)}

The flow through properties of the drill core column were investigated by following the migration of a conservative chloride tracer 


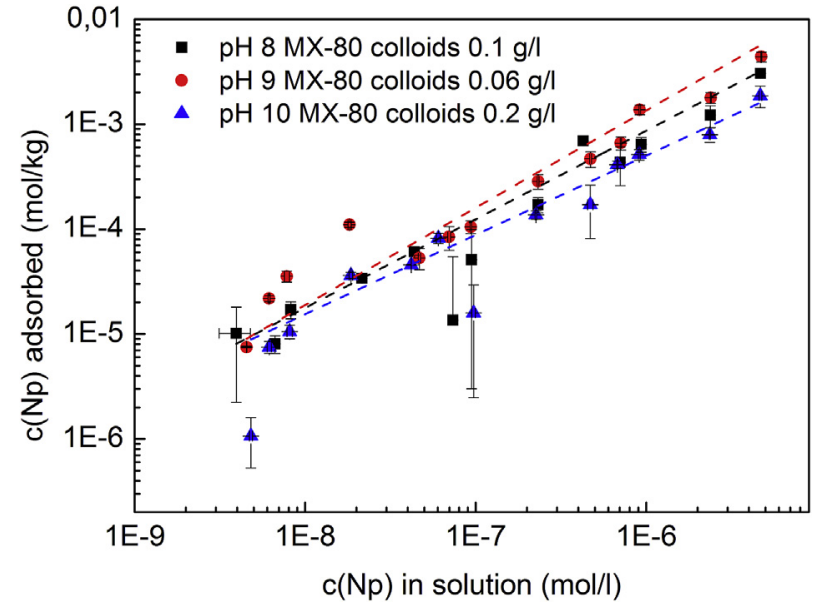

Fig. 5. Neptunium(V) sorption isotherms in $\mathrm{N}_{2}$-atmosphere on MX-80 colloids at $\mathrm{pH} 8\left(\mathrm{c}_{\text {colloids }}=0.1 \mathrm{~g} / \mathrm{L}\right), \mathrm{pH} 9(0.06 \mathrm{~g} / \mathrm{L})$ and $\mathrm{pH} 10(0.2 \mathrm{~g} / \mathrm{L})$. The neptunium $(\mathrm{V})$ concentration is $10^{-9}-5 \times 10^{-6}$.

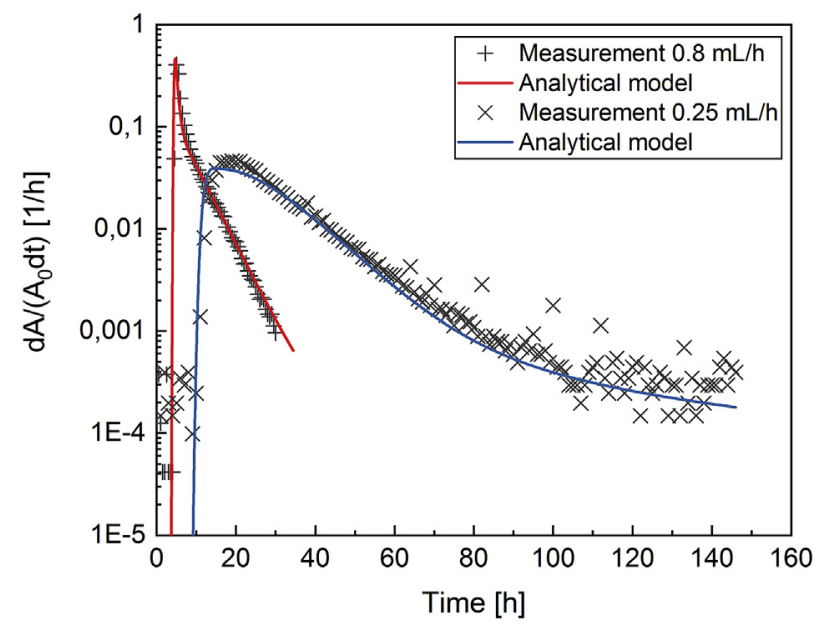

Fig. 6. Measured and modeled breakthrough curves of chloride in the absence of colloids through the drill core column. The chloride concentration in the injected tracer volume was $8.7 \times 10^{-2} \mathrm{M}$. The recoveries of the $\mathrm{Cl}-36$ tracer were approximately $100 \%$.

through the column at two different flow rates of $0.8 \mathrm{~mL} / \mathrm{h}$ and $0.25 \mathrm{~mL} / \mathrm{h}$ (Fig. 6).

In Fig. 6 the breakthrough of chloride can be seen to be governed by the flow velocity. As expected, the breakthrough occurs earlier for the faster flow rate, followed by a slight tailing at both flow velocities, which can be attributed to dispersion in the column as previously shown by Park et al. (2012). The modeled breakthrough curves are in good agreement with the measured ones. The modeling results in terms of velocity scaling and diffusion coefficients for chloride in water are compiled in Table 1.

The velocity scaling can be seen to vary from one measurement to another. This may be due to a slight displacement of the sample in the plastic tube resulting in a non-uniform aperture around the sample. The

Table 1

The modeling results of measured breakthrough curves of chloride from the drill core column using different flow rates. The results include the velocity scaling and the self-diffusion coefficient of the element in water $\left(D_{0}\right)$.

\begin{tabular}{llll}
\hline Element $(\mathrm{pH})$ & Flow rate $[\mathrm{mL} / \mathrm{h}]$ & Velocity scaling $[-]$ & $\mathrm{D}_{0}\left[\mathrm{~m}^{2} / \mathrm{s}\right]$ \\
\hline Cl-36 (8) & 0.8 & 5 & $3 \times 10^{-9}$ \\
Cl-36 (8) & 0.25 & 2.5 & $3 \times 10^{-9}$ \\
\hline
\end{tabular}

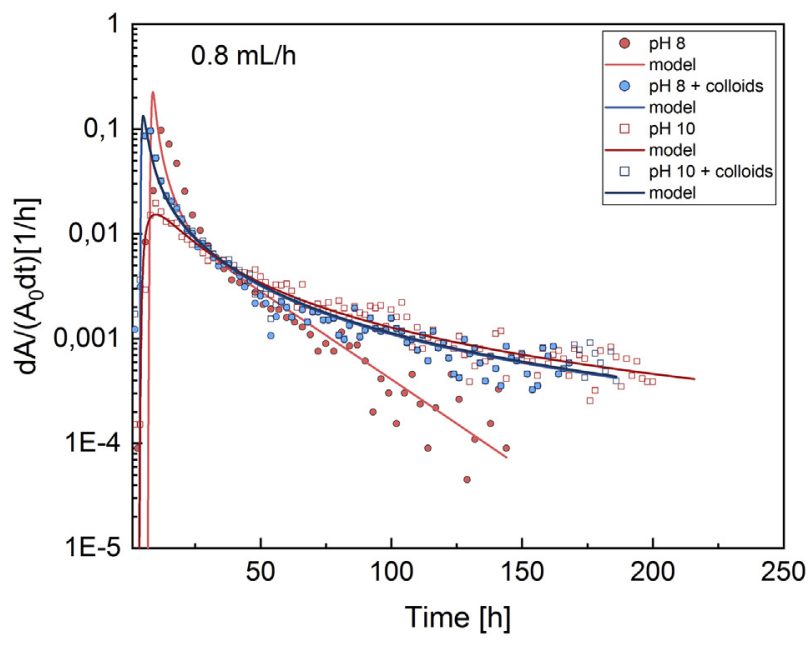

Fig. 7. Measured and modeled breakthrough curves for neptunium(V) through the drill core column at a flow rate of $0.8 \mathrm{~mL} / \mathrm{h}$ in $10 \mathrm{mM} \mathrm{NaClO}_{4}, \mathrm{pH} 8$ (closed symbols) and pH 10 (open symbols) in the absence (red traces) and presence of colloids (blue traces). The neptunium(V) recoveries at $\mathrm{pH} 8$ and $\mathrm{pH} 10$ were $95 \%$ and $68 \%$, respectively, in the absence of colloids. In the presence of colloids recoveries of $99 \%(\mathrm{pH} 8)$ and $98 \%(\mathrm{pH} \mathrm{10)}$ were obtained.

variation in the aperture of flow channels has caused channeling of the flow field. A direct consequence of the non-uniform aperture and the variations in the water flow, are the slightly higher values obtained in the present study for diffusion coefficients for chloride in water in comparison to the published value of $2.0 \times 10^{-9} \mathrm{~m}^{2} / \mathrm{s}$ (Bastug and Kuyucak, 2005). This compensates the effect arising from a larger interaction between the flowing and stagnant water than with the average aperture. However, the difference between the published and modeled diffusion coefficients for chloride in water is minor when taking into account the robustness of the experiment. In general, such channeling of the flow field is typical in natural systems and in artificial systems for fracture flows.

\subsubsection{Neptunium(V) and colloids}

Neptunium(V) breakthrough curves for the flow rate of $0.8 \mathrm{~mL} / \mathrm{h}$ in the absence (red symbols) and presence (blue symbols) of bentonite colloids in the drill core granite column experiments at $\mathrm{pH} 8$ and 10 are presented in Fig. 7. Results obtained for the flow rate of $0.3 \mathrm{~mL} / \mathrm{h}$ are presented in Fig. 8.

Breakthrough curves for the colloids are presented in Fig. 9. Here, only the results obtained for the flow rate of $0.3 \mathrm{~mL} / \mathrm{h}$ at $\mathrm{pH} 8$ have been collected together with the neptunium $(\mathrm{V})$ data presented above, by determining the mean particle size and derived count rate with PCS from all collected fractions. The colloid breakthrough curves for the experiments at $0.8 \mathrm{~mL} / \mathrm{h}, \mathrm{pH} 8$ and $0.3 \mathrm{~mL} / \mathrm{h}, \mathrm{pH} 10$ are results of separate experiments. The colloid concentrations in these experiments were $0.25 \mathrm{~g} / \mathrm{L}$ and $0.32 \mathrm{~g} / \mathrm{L}$, respectively. For the flow rate of $0.8 \mathrm{~mL} / \mathrm{h}$, the recoveries of colloids were $80 \pm 9 \%$ during the whole experiment. For the flow rate of $0.3 \mathrm{~mL} / \mathrm{h}$, the recoveries fluctuated between $65 \%$ and $98 \%$ in the beginning and thereafter decreased down to $20 \%$ suggesting filtration of colloids into the stagnant areas of the flow channel or tubing. The mean particle sizes stayed constant at $190 \pm 99 \mathrm{~nm}$ $(0.8 \mathrm{~mL} / \mathrm{h})$ and $220 \pm 85 \mathrm{~nm}(0.3 \mathrm{~mL} / \mathrm{h})$ over the whole collection time, which is in line with the results obtained in our colloid stability tests where a constant colloid size of $215 \pm 54 \mathrm{~nm}$ was maintained over 30 days $(720 \mathrm{~h})$.

\subsubsection{Discussion}

The modeled neptunium(V) breakthrough curves in the absence and presence of colloids are in good agreement with the measured ones. The modeling results in terms of velocity scaling and diffusion coefficients 


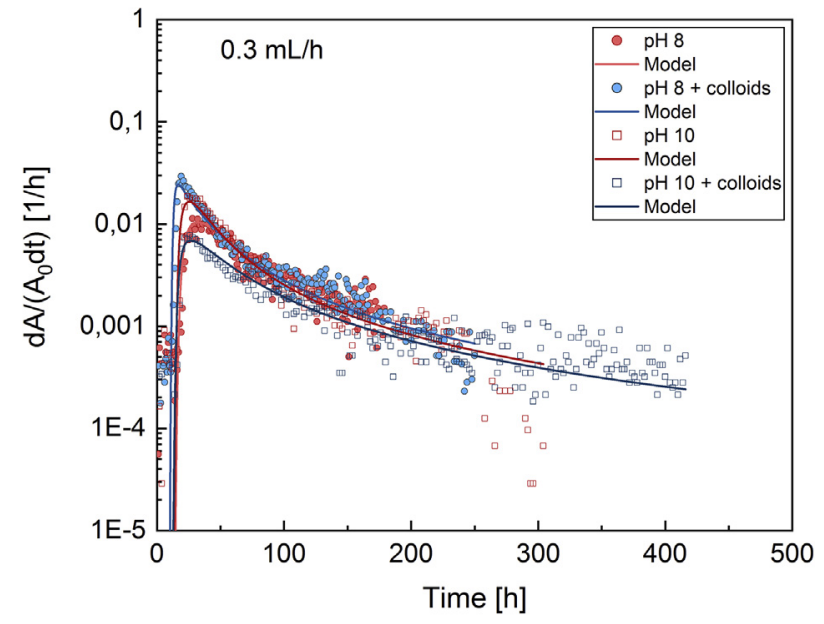

Fig. 8. Measured and modeled breakthrough curves for neptunium(V) through the drill core column, flow rates of $0.3 \mathrm{~mL} / \mathrm{h}$ in $10 \mathrm{mM} \mathrm{NaClO}_{4} \mathrm{pH} 8$ (closed symbols) and 10 (open symbols) in the absence (red traces) and presence of colloids (blue traces). The neptunium(V) recoveries at $\mathrm{pH} 8$ and $\mathrm{pH} 10$ were $96 \%$ and $92 \%$, respectively, in the absence of colloids. In the presence of colloids recoveries of $100 \%(\mathrm{pH} 8)$ and $60 \%(\mathrm{pH} 10)$ were obtained.

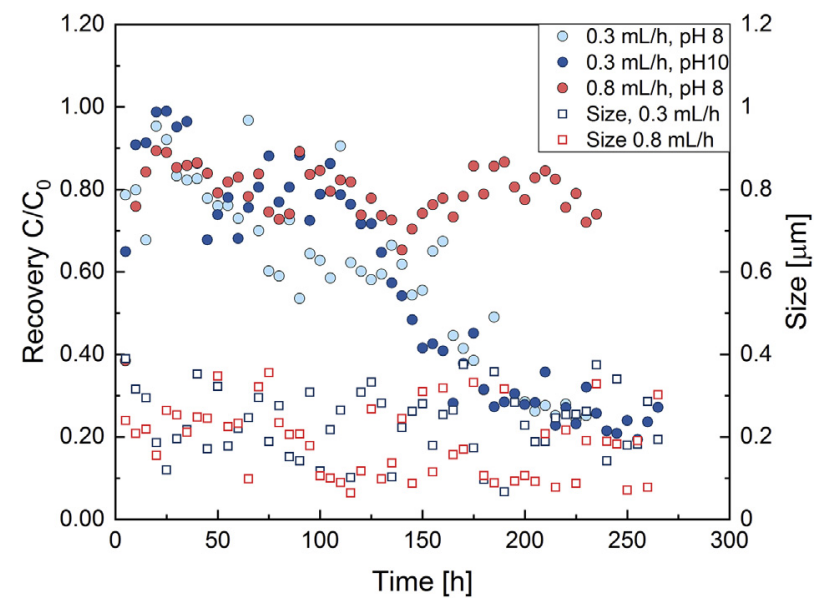

Fig. 9. The breakthrough and mean particle size of colloids. The colloid breakthrough at $0.3 \mathrm{~mL} / \mathrm{h}, \mathrm{pH} 8$ (light blue spheres, $0.08 \mathrm{~g} / \mathrm{L}$ ) was determined from the neptunium $(\mathrm{V})$ experiment in the presence of colloids. The breakthrough at $0.3 \mathrm{~mL} / \mathrm{h}, \mathrm{pH} 10(0.32 \mathrm{~g} / \mathrm{L})$ and $0.8 \mathrm{~mL} / \mathrm{h}, \mathrm{pH} 8(0.25 \mathrm{~g} / \mathrm{L})$ (blue and red spheres) as well as mean particle sizes (squares) are determined from separate colloid breakthrough experiments.

Table 2

The neptunium(V) recoveries and modeling results of measured breakthrough curves from the drill core column using different flow rates. The modeling results include the velocity scaling and the sorption distribution coefficient $\left(\mathrm{K}_{\mathrm{d}}\right)$. The self-diffusion coefficient of the element in water $\left(D_{0}\right)$ was $3 \times 10^{-9} \mathrm{~m}^{2} / \mathrm{s}$ in all cases.

\begin{tabular}{lllll}
\hline Element (pH) & $\begin{array}{l}\text { Flow rate } \\
{[\mathrm{mL} / \mathrm{h}]}\end{array}$ & $\begin{array}{l}\text { velocity } \\
\text { scaling [-] }\end{array}$ & $\mathrm{K}_{\mathrm{d}}\left[\mathrm{m}^{3} / \mathrm{kg}\right]$ & $\begin{array}{l}\mathrm{Np}-237 \\
\text { recovery [\%] }\end{array}$ \\
\hline $\mathrm{Np}-237(8)$ & 0.8 & 1 & $8 \times 10^{-5}$ & 95 \\
$\mathrm{~Np}-237+\operatorname{col}(8)$ & 0.8 & 2 & 0.003 & 99 \\
$\mathrm{~Np}-237(10)$ & 0.8 & 2 & 0.004 & 68 \\
$\mathrm{~Np}-237+\operatorname{col}(10)$ & 0.8 & 2 & 0.003 & 98 \\
$\mathrm{~Np}-237(8)$ & 0.3 & 1.5 & 0.0009 & 96 \\
$\mathrm{~Np}-237+\operatorname{col}(8)$ & 0.3 & 2 & 0.0005 & 100 \\
$\mathrm{~Np}-237(10)$ & 0.3 & 1.5 & 0.001 & 92 \\
$\mathrm{~Np}-237+\operatorname{col}(10)$ & 0.3 & 1.7 & 0.002 & 60 \\
\hline
\end{tabular}

for neptunium in water are compiled in Table 2.

The observed rapid increase of the breakthrough curves obtained for the intact drill core column are mainly governed by the ratio between stagnant and flowing water in the columns. In the experiments conducted at the slower flow rate (Fig. 8), the pre-peak position remains constant in the presence and absence of colloids, while a shift can be seen for the $0.8 \mathrm{~mL} / \mathrm{h}$ data. The observed differences in this pre-peak position must, thus, originate from slight differences of the drill core position in the plastic tubes during the breakthrough experiments. The modeled breakthrough curves (Figs. 7 and 8) show that the flow field is channeled in the neptunium(V) experiments and that typically about half of the flow channel has flowing water (see Table 2). The raise of the breakthrough curve is not as steep as for chloride. This demonstrates that the flow field cannot be fully modeled with the simple dual flow velocity model as the sorbing nuclide interaction with the rock matrix is stronger than such models predicts. However, in this case the late part of the breakthrough curve cannot be explained by only matrix diffusion into stagnant water and later back to the flowing area and, thus, sorption affects the late part of the breakthrough curve.

A higher tail of the breakthrough curves, especially at the flow velocity of $0.8 \mathrm{~mL} / \mathrm{h}$, can be seen with increasing $\mathrm{pH}$ in the absence of colloids, indicating that neptunium(V) sorbs on the granite surface as also observed in our batch sorption studies on the crushed material (Fig. 4). This can also be seen from the $K_{d}$ values determined by the modeling (Table 2). Here, the $K_{d}$ values for neptunium(V) without colloids vary from $8 \times 10^{-5} \mathrm{~m}^{3} / \mathrm{kg}$ to $0.004 \mathrm{~m}^{3} / \mathrm{kg}$. These values are between 10 and 200 times lower than obtained in our batch sorption experiments $\left(\sim 0.015-0.030 \mathrm{~m}^{3} / \mathrm{kg}, \mathrm{pH}=8-10\right)$. Such a large discrepancy could be a result of a much smaller specific surface area of the column material in comparison to the crushed granite material used in the batch sorption experiments. In Hölttä et al. (1997), a specific surface area of $0.05-0.07 \mathrm{~m}^{2} / \mathrm{g}$ and $1.2 \mathrm{~m}^{2} / \mathrm{g}$ for intact and crushed tonalitic rock, respectively, has been reported, i.e. a difference of a factor of approximately 20. Other factors such as a slow sorption kinetic for neptunium(V) uptake by granite, as shown in Park et al. (2012) could play a role in addition to a high reversibility of neptunium(V) sorption under flowing water conditions as was shown for neptunium(V) uptake by montmorillonite in our previous study (Elo et al., 2017). Slow sorption kinetics is supported by the results obtained at $\mathrm{pH}=8$, where more than 10 times higher sorption distribution coefficient is obtained for the $0.3 \mathrm{~mL} / \mathrm{h}$ flow rate in comparison to the $0.8 \mathrm{~mL} / \mathrm{h}$ one. This is well in agreement with the overall neptunium(V) column residence time, which was approximately 4 days for $0.3 \mathrm{~mL} / \mathrm{h}$ and only $25 \mathrm{~h}$ for the $0.8 \mathrm{~mL} / \mathrm{h}$ experiment, whereas the equilibration time for batch sorption studies was 7 days. The residence time is taken as the time between tracer injection and elution through the column. At $\mathrm{pH}=10$ the sorption distribution coefficient is of the same order of magnitude for both flow rates. Whether this is an effect of the stagnant vs. flowing water volume which is systematically higher for the larger flow rate (see Tables 1 and 2) or due to changes in the surface complexation mode (e.g. larger amount of inner-sphere sorption at $\mathrm{pH}=10$ ), we cannot deduce based on available data. Thus, for a proper assessment of the underlying reasons between differences in neptunium(V) uptake under stagnant vs. flowing water conditions, detailed understanding of sorption kinetics, reversibility of the sorption reaction, and knowledge of the complexation mechanism on the solid surface are required.

The presence of colloids has almost no influence on the neptunium (V) breakthrough at the slower flow rate of $0.3 \mathrm{~mL} / \mathrm{h}$ and at the higher $\mathrm{pH}$ for the $0.8 \mathrm{~mL} / \mathrm{h}$ flow rate. Based on our batch sorption data, a constant uptake of neptunium(V) of around $10 \%$ of the total neptunium (V) concentration is expected by the bentonite colloids at $\mathrm{pH}=8$ and 10. In the granite column the sorption percentage is more difficult to assess, as the solid to liquid ratio is unknown. However, a larger amount of neptunium(V) sorption is expected at $\mathrm{pH}=10$ on the column material, implying that a potential influence of the colloids should be more pronounced at this $\mathrm{pH}$-value. Such an influence, however, is not seen in 


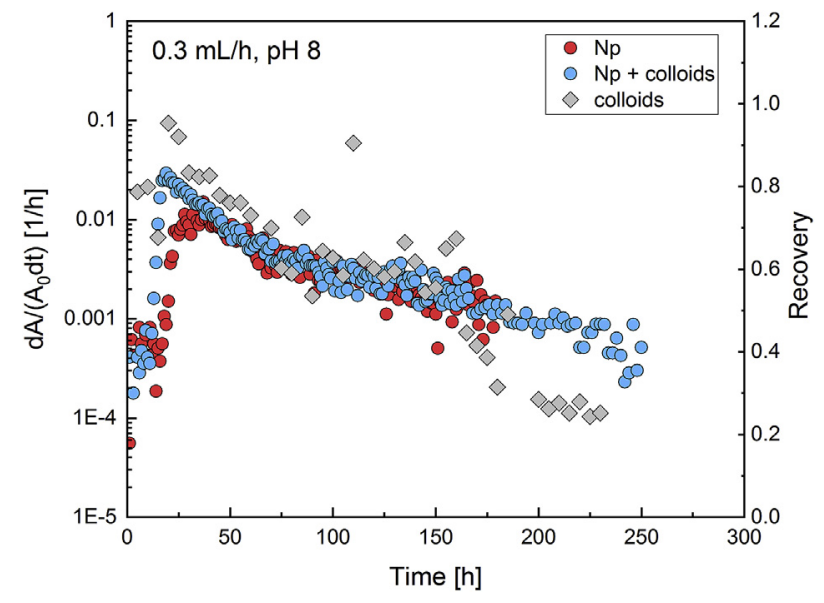

Fig. 10. Comparison between the breakthrough behavior of neptunium(V) (red and light blue symbols), and the breakthrough (grey symbols) of colloids at the flow velocity of $0.3 \mathrm{~mL} / \mathrm{h}$ and $\mathrm{pH}=8$.

our column studies. At the $0.3 \mathrm{~mL} / \mathrm{h}$ flow rate, almost no retention of neptunium $(\mathrm{V})$ can be seen on the column material both in the presence and absence of colloids. Therefore, it is difficult to assess if the eluted neptunium $(\mathrm{V})$ in the presence of colloids is associated with the colloids or migrating with the flowing water. The colloid breakthrough behavior at this flow velocity seems to oscillate between 60 and $100 \%$ recoveries before it decreases toward $20 \%$. As already briefly mentioned, this decrease of the colloid breakthrough is most likely a result of filtration of colloids into the stagnant areas of the flow channel or tubing. A similar oscillating breakthrough of neptunium(V) is not observed, which would imply that at least the majority of neptunium(V) is eluted from the column in the aqueous phase. A slight indication for colloid-borne neptunium(V), however, is visible after approximately $160 \mathrm{~h}$ (Fig. 10) when comparing the breakthrough behavior of neptunium $(\mathrm{V})$ with that of the colloids. The abrupt decrease of colloid breakthrough (grey symbols) at this time point is associated with a small kink in the neptunium(V) breakthrough curve (light blue symbols).

At $\mathrm{pH} 10$, both flow rates show a small difference in the sorption distribution coefficient in the presence of colloids. The difference, however, is not systematic, i.e. a slightly lower $\mathrm{K}_{\mathrm{d}}$ value is obtained at $0.8 \mathrm{~mL} / \mathrm{h}$ while the opposite is true at $0.3 \mathrm{~mL} / \mathrm{h}$ in the presence of bentonite colloids. Therefore, this difference can most likely be attributed to the experimental error in the column investigations and their modeling rather than to an actual effect caused by the colloids. The situation, however, is very different at $\mathrm{pH}=8$ for the faster flow rate, where a steeper tailing of the breakthrough curve can be seen in the absence of colloids (Fig. 7), implying that a higher retention of neptunium(V) in the column occurs in the presence of colloids. This is also supported by the modeled $\mathrm{K}_{\mathrm{d}}$ values which are larger in the presence of colloids than in the absence of them by a factor of almost 40 . As there is almost no retention to be seen on the granite in the absence of colloids, the enhanced uptake by the colloids could be related to the adsorption of colloids on the column material, providing further sorption sites for neptunium(V) attachment inside the column. Alternatively, colloids may interrupt the flow path, reducing the accessible flow channels for neptunium $(\mathrm{V})$ and therefore influence the breakthrough properties of neptunium(V). Such a clogging phenomenon of colloids was observed by Missana et al. (2008). When looking at the colloid breakthrough curve at this flow velocity and $\mathrm{pH}$, a similar oscillating behavior can be seen as for the lower flow velocity of $0.3 \mathrm{~mL} / \mathrm{h}$. However, the recovery never reaches $100 \%$ (oscillation occurs between 70 and $90 \%$ ) and there is no decrease of the colloid recovery as observed for the slower flow velocity. Thus, a clogging phenomenon cannot be confirmed based on the colloid breakthrough data and we must explore the possibility of colloid attachment on the column material resulting in the retention of colloid-borne neptunium(V) in the column. The point of zero charge or isoelectric point of granite has been reported to lie around $\mathrm{pH} 8-9$ (Charalambos P., 2001; Chen T. et al., 2013). The IEP for bentonite colloids is much lower. In fact, we measured a constant negative charge of montmorillonite over the entire examined pH-range of 3-11 (Elo et al., 2017). At pH 8 some of the surface groups on granite still carry a positive charge, thus, enabling the electrostatic attachment of colloids on the surface. At pH 10 such electrostatic attachment will be decreased due to the larger amount of negatively charged surface groups. However, if pH-dependent colloid attachment on granite occurs, the effect should be visible also at $\mathrm{pH} 8$, which is not the case in our column experiments. Thus, a definite conclusion of the underlying reasons for the decreased breakthrough of neptunium(V) in the presence of colloids at $\mathrm{pH} 8$ and the flow velocity of $0.8 \mathrm{~mL} / \mathrm{h}$ cannot be given.

\section{Conclusions}

In this study, we investigated the influence of MX-80 bentonite colloids on neptunium(V) migration in granite media. Neptunium(V) uptake by crushed granite was found to be pH-dependent, whereas neptunium(V) uptake by MX-80 bentonite colloids was pH-independent, unlike observed for montmorillonite purified from the MX80 bentonite. The column experiments under flowing water conditions were conducted for chloride as a non-sorbing tracer and for neptunium (V) at two $\mathrm{pH}$ values $(\mathrm{pH}=8$ and 10$)$ and two flow rates $(0.3 \mathrm{~mL} / \mathrm{h}$ and $0.8 \mathrm{~mL} / \mathrm{h}$ ). The resulting breakthrough curves were thereafter modeled using the analytical solution of advection-matrix diffusion equation in cylindrical coordinates. The modeling results of chloride breakthrough curves indicated that the flow field consisted of flowing and stagnant water and that tail of the breakthrough curve was caused by matrix diffusion into the stagnant water and later back into flowing water. The modeling results for neptunium(V) breakthrough curves were in good agreement with the experimental results. A tailing of neptunium(V) breakthrough curves in comparison to the conservative tracer was observed, which could be explained by a higher retardation of neptunium (V) in the column caused by sorption on the granite. The sorption was in general lower at $\mathrm{pH} 8$ than at $\mathrm{pH}$ 10. In addition, the tailing was almost identical in the absence and presence of MX- 80 bentonite colloids, implying that the influence of colloids on the neptunium(V) mobility is almost negligible. With respect to conditions in the repository environment where $\mathrm{pH}$ ranges from circumneutral to slightly alkaline, and the groundwater is mildly oxic e.g. due to the glacial melt waters, the migration of neptunium(V) is favored due to low sorption onto granite media. Therefore, at low flow rates matrix diffusion becomes an important process retarding neptunium migration under oxic conditions.

\section{Acknowledgements}

This research was financially supported by the European Atomic Energy community's Seventh Framework Programme (FP7/ 2007-2011) under grant agreement no 295487 and Finnish Research Programme on Nuclear Waste Management (KYT 2018) funded by the State Nuclear Waste Management Fund (VYR).

\section{References}

Alonso, U., Missana, T., Geckeis, H., García-Gutiérrez, M., Turrero, M.J., Möri, R., Schäfer, T., Patelli, A., Rigato, V., 2006. Role of inorganic colloids generated in a high-level deep geological repository in the migration of radionuclides; open questions. J. Iber. Geol. 32 (1), 79-94 Research and development for the deep geological disposal of radioactive wastes; I.

Artinger, R., Kienzler, B., Schüßler, W., Kim, J.I., 1998. Effects of humic substances on the ${ }^{241} \mathrm{Am}$ migration in a sandy aquifer: column experiments with Gorleben groundwater/sediment systems. J. Contam. Hydrol. 35, 261-275.

Bachmaf, S., Planer-Friedrich, B., Merkel, B.J., 2008. Effect of sulfate, carbonate, and phosphate on the uranium(VI) sorption behavior onto bentonite. Radiochim. Acta 96, 359-366.

Baik, M.H., Cho, W.J., Hahn, P.S., 2007. Erosion of bentonite particles at the interface of a 
compacted bentonite and a fractured granite. Eng. Geol 91, 229-239.

Bastug, T., Kuyucak, S., 2005. Temperature dependence of the transport coefficients of ions from molecular dynamics simulations. Chem. Phys. Lett. 408, 84-88.

Begg, J.D., Zavarin, M., Tumey, S.J., Kersting, A.B., 2015. Plutonium sorption and desorption behavior on bentonite. J. Environ. Radioact. 141, 106-114.

Buckau, G., Artinger, R., Fritz, P., Geyer, S., Kim, J.I., Wolf, M., 2000. Origin and mobility of humic colloids in the Gorleben aquifer system. Appl. Geochem. 15, 171-179.

Buddemeier, R.W., Hunt, J.R., 1988. Transport of colloidal contaminants in groundwater: radionuclide migration at the Nevada Test Site. Appl. Geochem. 3, 535-548.

Charalambos, P., 2001. Cation and anion sorption on granite from the project shoal test area, near fallon, Nevada, USA. Adv. Environ. Res. 5, 151-166.

Chen, T., Li, C., Liu, X.Y., Wang, L.H., Zheng, Z., Wang, X.Y., Liu, C.L., 2013. Migration study of iodine in Beishan granite by a column method. J. Radioanal. Nucl. Chem. 298, 219-225.

Degueldre, C., Baeyens, B., Goerlich, W., 1988. Colloids in water from a subsurface fracture in granitic rock, Grimsel Test Site, Switzerland. Geochem. Cosmochim. Acta $53,603-610$.

Degueldre, C., Grauer, R., Laube, A., Oess, A., Silby, H., 1996. Colloid properties in granitic groundwater systems. II: stability and transport study. Appl. Geochem. 11, 697-710.

Dittrich, T.M., Boukhalfa, H., Ware, S.D., Reimus, P.W., 2015. Laboratory investigation of the role of desorption kinetics on americium transport associated with bentonite colloids. J. Environ. Radioact. 148, 170-182.

Elo, O., 2014. Neptunium Sorption on Corundum, Montmorillonite and Bentonite Colloids. Master's Thesis. University of Helsinki.

Elo, O., Müller, K., Bok, F., Ikeda-Ohno, A., Scheinost, A.C., Hölttä, P., Huittinen, N. 2017. Batch sorption and spectroscopic speciation studies of neptunium uptake by montmorillonite and corundum. Geochim. Cosmochim. Acta 198, 168-181.

Finn, P.A., Bates, J.K., Hoh, J.C., Emery, J.W., Hafenrichter, L.D., Buck, E.C., Gong, M., 1993. Elements present in leach solutions from unsaturated spent fuel tests. In: Scientific Basis for Nuclear Waste Management XVII, MRS Proceedings, vol. 333. pp. 399-404.

García-García, S., Wold, S., Jonsson, M., 2007. Kinetic determination of critical coagulation concentration for sodium and calcium montmorillonite colloids in $\mathrm{NaCl}$ and $\mathrm{CaCl}_{2}$ aqueous solutions. J. Colloid Interface Sci. 315, 512-519.

Geckeis, H., Schäfer, T., Hauser, W., Rabung, Th., Missana, T., Degueldre, C., Möri, A., Eikenberg, J., Fierz, Th., Alexander, W.R., 2004. Results of the colloid and radionuclide retention experiment (CRR) at the Grimsel Test Site (GTS), Switzerland impact of reaction kinetics and speciation on radionuclide migration. Radiochim. Acta 92, 765-774.

Huber, F., Kunze, P., Geckeis, H., Schäfer, T., 2011. Sorption reversibility kinetics in the ternary system radionuclide-bentonite colloids/nanoparticles-granite fracture filling material. Appl. Geochem. 26, 2226-2237.

Hummel, W., 2008. Radioactive contaminants in the subsurface: the influence of complexing ligands on trace metal speciation. Monatsh. Chem. 139, 459-480.

Hursthouse, A.S., Baxter, M.S., Livens, F.R., Duncan, H.J., 1991. Transfer of sellafieldderived Np-237 to and within the terrestrial environment. J. Environ. Radioact. 14, 147-174.

Hölttä, P., Hakanen, M., Hautojärvi, A., Timonen, J., Väätäinen, K., 1996. The effects of matrix diffusion on radionuclide migration in rock column experiments. J. Contam. Hydrol. 21, 165-173.

Hölttä, P., Siitari-Kauppi, M., Hakanen, M., Huitti, T., Hautojärvi, A., Lindberg, A., 1997. Radionuclide transport and retardation in rock fracture and crushed rock colum experiments. J. Contam. Hydrol. 26, 135-145.

Hölttä, P., Poteri, A., Hakanen, M., Hautojärvi, A., 2004. Fracture flow and radionuclide transport in block-scale laboratory experiments. Radiochim. Acta 92, 775-779.

Hölttä, P., Poteri, A., Siitari-Kauppi, M., Huittinen, N., 2008. Retardation of mobile radionuclides in granitic rock fractures by matrix diffusion. Phys. Chem. Earth 33, 983-990.

Ikonen, J., Voutilainen, M., Söderlund, M., Jokelainen, L., Siitari-Kauppi, M., Martin, A., 2016. Sorption and diffusion of selenium oxyanions in granitic rock. J. Contam. Hydrol. 192, 203-211.

Jansson, M., 2009. Bentonite Erosion, Laboratory Studies. SKB Technical Report TR-0933. .

Jokelainen, L., Ikonen, J., Read, D., Hellmuth, K.-H., Siitari-Kauppi, M., 2009. The diffusion of tritiated water, chloride and uranium through granite. In: Scientific Basis for Nuclear Waste Management XXXIII, MRS Proceedings, vol. 1193. pp. 461-468.

Kaszuba, J.P., Runde, W.H., 1999. The aqueous geochemistry of neptunium: dynamic control of soluble concentrations with applications to nuclear waste disposal. Environ. Sci. Technol. 33, 4427-4433.

Kekäläinen, P., Voutilainen, M., Poteri, A., Hölttä, P., Hautojärvi, A., Timonen, J., 2011. Solutions to and validation of matrix-diffusion models. Transp. Porous Med. 87 (1), 125-149.

Kekäläinen, P., 2014. Analytical solutions to matrix diffusion problems. AIP Conference Proceedings 1618, 513-516.

Kersting, A.B., Efurd, D.W., Finnegan, D.L., Rokop, D.J., Smith, D.K., Thompson, J.L., 1999. Migration of plutonium in ground water at the Nevada Test Site. Nature 397, 56-59.

Kienzler, B., Vejmelka, P., Römer, J., Fanghänel, E., Jansson, M., Eriksen, T.E., Wikberg, P., 2003. Swedish-German actinide migration experiment at ÄSPÖ hard rock laboratory. J. Contam. Hydrol. 61, 219-233.

Kumata, M., Vandergraaf, T.T., 1998. Experimental study on neptunium migration under in situ geochemical conditions. J. Contam. Hydrol. 35, 31-40.

Kumpulainen, S., Kiviranta, L., 2010. Mineralogical and chemical characterization of various bentonite and smectites rich clay materials. Posiva Working Report 2010-2052.

Kuva, J., Voutilainen, M., Kekäläinen, P., Siitari-Kauppi, M., Sammaljärvi, J., Timonen, J., Koskinen, L., 2016. Gas phase measurements of matrix diffusion in rock samples from
Olkiluoto bedrock. Finland. Transp. Porous Med. 115, 1-20.

Laaksoharju, M., Wold, S., 2005. The Colloid Investigations Conducted at the Äspö Hard Rock Laboratory during 2000-2004. SKB Technical Report TR-05-20.

Lagaly, G., Ziesmer, S., 2003. Colloid chemistry of clay minerals: the coagulation of montmorillonite dispersions. Adv. Colloid Interface Sci. 100-102, 105-128.

Lahtinen, M., Hölttä, P., Riekkola, M.L., Yohannes, G., 2010. Analysis of colloids released from bentonite and crushed rock. Phys. Chem. Earth, Parts A/B/C 35, 265-270.

Li, P., Liu, Z., Ma, F., Shi, Q.L., Guo, Z.J., Wu, W.S., 2015. Effects of pH, ionic strength and humic acid on the sorption of neptunium(V) to Na-bentonite. J. Mol. Liq. 206, 285-292.

Moreno, L., Gylling, B., Neretnieks, I., 1997. Solute transport in fractured media the important mechanisms for performance assessment. J. Contam. Hydrol. 25, 283-298.

Missana, T., Alonso, U., Turrero, M.J., 2003. Generation and stability of bentonite colloids at the bentonite/granite interface of a deep geological radioactive waste repository. J. Contam. Hydrol. 61, 17-31.

Missana, T., García-Gutiérrez, M., Alonso, U., 2004. Kinetics and irreversibility of cesium and uranium sorption onto bentonite colloids in a deep granitic environment. Appl. Clay Sci. 26, 137-150.

Missana, T., Alonso, U., García-Gutiérrez, M., Mingarro, M., 2008. Role of bentonite colloids on europium and plutonium migration in a granite fracture. Appl. Geochem. 23, 1484-1497.

Missana, T., Alonso, U., Albarran, N., García-Gutiérrez, M., Cormenzana, J. 1., 2011. Analysis of colloids erosion from the bentonite barrier of a high level radioactive waste repository and implications in safety assessment. Phys. Chem. Earth 36, $1607-1615$.

Möri, A., Alexander, W.R., Geckeis, H., Hauser, W., Schäfer, T., Eikenberg, J., Fierz, Th, Degueldre, C., Missana, T., 2003. The colloid and radionuclide retardation experiment at the Grimsel Test Site: influence of bentonite colloids on radionuclide migration in a fractured rock. Colloid. Surface. Physicochem. Eng. Aspect. 217, 33-47.

Niemiaho, S., 2013. Bentoniittikolloidien Kulkeutuminen Ja Vaikutus Sr-85 Ja Eu-152 Liikkuvuuteen Graniittisessa Kivessä. Master's Thesis. University of Helsinki.

Novikov, A.P., Kalmykov, S.N., Utsunomiya, S., Ewing, R.C., Horreard, F., Merkulov, A., Clark, S.B., Tkachev, V.V., Myasoedov, B.F., 2006. Colloid transport of plutonium in the far-field of the Mayak Production Association, Russia. Science 314, 638-641.

Park, C., Kienzler, B., Vejmelka, P., Jeong, J., 2012. Modeling and analysis of the migration of HTO and ${ }^{237} \mathrm{~Np}$ in a fractured granite core at the Äspö hard rock laboratory. Radiochim. Acta 100, 197-205.

Puls, R.W., Powell, R.M., 1992. Transport of inorganic colloids through natural aquifer material: implications for contaminant transport. Environ. Sci. Technol. 26, 614-621.

Ren, X., Wang, S., Yang, S., Li, J., 2010. Influence of contact time, pH, soil humic/fulvic acids, ionic strength and temperature on sorption of U(VI) onto MX-80 bentonite. J. Radioanal. Nucl. Chem. 283, 253-259.

Ryan, J.N., Elimelech, M., 1996. Colloid mobilization and transport in groundwater. Colloids Surf., A 107, 1-56.

Sabodina, M.N., Kalmykov, S.N., Sapozhnikov, Y.A., Zakharova, E.V., 2006. Neptunium, plutonium and ${ }^{137} \mathrm{Cs}$ sorption by bentonite clays and their speciation in pore waters. J. Radioanal. Nucl. Chem. 270, 349-355.

Schäfer, T., Geckeis, H., Bouby, M., Fanghänel, T., 2004. U, Th, Eu and colloid mobility in a granite fracture under near-natural flow conditions. Radiochim. Acta 92, 731-737.

Schäfer, T., Huber, F., Seher, H., Missana, T., Alonso, U., Kumke, M., Eidner, S., Claret, F., Enzmann, F., 2012. Nanoparticles and their influence on radionuclide mobility in deep geological formations. Appl. Geochem. 27, 390-403.

Short, S.A., Lowson, R.T., Ellis, J., 1988. $\mathrm{U}^{234} / \mathrm{U}^{238}$ and $\mathrm{Th}^{230} / \mathrm{U}^{234}$ activity ratios in the colloidal phases of aquifers in lateritic weathered zones. Geochim. Cosmochim. Acta 52, 2555-2563.

Smith, P.A., Degueldre C., 1993. Colloid-facilitated transport of radionuclides through fractured media. J. Contam. Hydrol. 13, 143-166.

Tombácz, E., Szekeres, M., 2004. Colloidal behavior of aqueous montmorillonite suspensions: the specific role of $\mathrm{pH}$ in the presence of indifferent electrolytes. Appl. Clay Sci. 27, 75-94.

Torok, J., Buckley, L.P., Woods, B.L., 1990. The separation of radionuclide migration by solution and particle transport in soil. J. Contam. Hydrol. 6, 185-203.

Verma, P.K., Pathak, P.N., Mohapatra, P.K., Godbole, S.V., Kadam, R.M., Veligzhanin, A.A., Zubavichus, Y.V., Kalmykov, S.N., 2014. Influences of different environmental parameters on the sorption of trivalent metal ions on bentonite: batch sorption, fluorescence, EXAFS and EPR studies. Environ. Sci.: Processes Impacts 16, 904-915.

Verma, P.K., Romanchuk, A.Y., Vlasova, I.E., Krupskaya, V.V., Zakusin, S.V., Sobolev, A.V., Egorov, A.V., Mohapatra, P.K., Kalmykov, S.N., 2017. Neptunium(V) uptake by bentonite clay: effect of accessory Fe oxides/hydroxides on sorption and speciation. Appl. Geochem. 78, 74-82.

Vilks, P., Cramer, J.J., Bachinski, D.B., Doern, D.C., Miller, H.G., 1993. Studies of colloids and suspended particles, cigar lake uranium deposit, Saskatchewan, Canada. Appl. Geochem. 8, 605-616.

Vilks, P., Baik, M.H., 2001. Laboratory migration experiments with radionuclides and natural colloids in a granite fracture. J. Contam. Hydrol. 47, 197-210.

Voutilainen, M., Kekäläinen, P., Poteri, A., Siitari-Kauppi, M., Helariutta K., Andersson P., Nilsson K., Yli-Kaila, M., Koskinen, L., 2019. Comparison of water phase diffusion experiments in the in-situ and laboratory conditions. (Submitted for publication).

Zhao, D.L., Feng, S.J., Chen, C.L., Chen, S.H., Xu, D., Wang, X.K., 2008. Adsorption of thorium(IV) on MX-80 bentonite: effect of pH, ionic strength and temperature. Appl. Clay Sci. $41,17-23$.

Zhao, P., Tinnacher, R.M., Zavarin, M., Kersting, A.B., 2014. Analysis of trace neptunium in the vicinity of underground nuclear tests at the Nevada National Security Site. J. Environ. Radioact. 137, 163-172.

Zong, P., Wu, X., Gou, J., Lei, X., Liu, D., Deng, H., 2015. Immobilization and recovery of uranium(VI) using Na-bentonite from aqueous medium: equilibrium, kinetics and thermodynamics studies. J. Mol. Liq. 209, 358-366. 